\title{
X-ray micro-computed tomography (micro-CT) of pyrite- permineralized fruits and seeds from the London Clay Formation (Ypresian) conserved in silicone oil: a critical evaluation
}

\begin{tabular}{|r|l|}
\hline Journal: & Botany \\
\hline Manuscript ID & cjb-2016-0078.R1 \\
\hline Manuscript Type: & Article \\
\hline Complete List of Authors: & $\begin{array}{l}\text { Collinson, Margaret; Royal Holloway University of London, Department of } \\
\text { Earth Sciences } \\
\text { Adams, Neil; Royal Holloway University of London, Departments of Earth } \\
\text { Sciences and Geography } \\
\text { Manchester, Steven; Florida Museum of Natural History, Department of } \\
\text { Biology and Florida Museum of Natural History } \\
\text { Stull, Gregory; University of Florida, Florida Museum of Natural History } \\
\text { Herrera, Fabiany; Chicago Botanic Garden, Plant Science Center } \\
\text { Smith, Selena; University of Michigan, Earth \& Environmental Sciences } \\
\text { Andrew, Mary; Royal Holloway University of London, Department of Earth } \\
\text { Sciences } \\
\text { Kenrick, Paul; Natural History Museum, Department of Earth Sciences } \\
\text { Sykes, Dan; University of Manchester, School of Materials }\end{array}$ \\
\hline Keyword: & $\begin{array}{l}\text { early Eocene, fossil plants, London Clay Formation, micro-CT, Natural } \\
\text { History Museum, London (NHMUK) }\end{array}$ \\
\hline
\end{tabular}


X-ray micro-computed tomography (micro-CT) of pyrite-permineralized fruits and seeds from the London Clay Formation (Ypresian) conserved in silicone oil: a critical evaluation

Margaret E. Collinson, Neil F. Adams, Steven R. Manchester, Gregory W. Stull, Fabiany Herrera, Selena Y. Smith, Mary J. Andrew, Paul Kenrick and Dan Sykes.

Margaret E. Collinson. Department of Earth Sciences, Royal Holloway University of London, Egham, Surrey, TW20 0EX, UK; Department of Earth Sciences, Natural History Museum, Cromwell Road, London, SW7 5BD, UK (email: M.Collinson@rhul.ac.uk).

Neil F. Adams. Departments of Earth Sciences and Geography, Royal Holloway University of London, Egham, Surrey, TW20 0EX, UK (email:

Neil.Adams.2012@live.rhul.ac.uk).

Steven R. Manchester. Department of Biology and Florida Museum of Natural History, University of Florida, Gainesville, FL 32611, USA (email: steven@flmnh.ufl.edu).

Gregory W. Stull. Department of Biology and Florida Museum of Natural History, University of Florida, Gainesville, FL 32611, USA (email: gwstull@gmail.com). 
Fabiany Herrera. Chicago Botanic Garden, 1000 Lake Cook Road, Glencoe, Illinois 60022, USA (e-mail: fherrera@chicagobotanic.org).

Selena Y. Smith. Department of Earth and Environmental Sciences and Museum of Paleontology, University of Michigan, Ann Arbor, MI 48109, USA (email: sysmith@umich.edu).

Mary J. Andrew. Department of Earth Sciences, Royal Holloway University of London, Egham, Surrey, TW20 0EX, UK (email: mary.andrew@outlook.com)

Paul Kenrick. Department of Earth Sciences, Natural History Museum, Cromwell Road, London, SW7 5BD, UK (email: p.kenrick@nhm.ac.uk).

Dan Sykes. Imaging and Analysis Centre, Natural History Museum, London, SW7 5BD, UK. Current affiliation: School of Materials, University of Manchester, Oxford Road, Manchester, M13 9PL, UK (email: dan.sykes@postgrad.manchester.ac.uk).

Corresponding author: Margaret E Collinson (email: M.Collinson@rhul.ac.uk; telephone: N/A: fax: N/A; address: Department of Earth Sciences, Royal Holloway University of London, Egham, Surrey, TW20 0EX, UK. 


\begin{abstract}
Pyrite-permineralized fruits and seeds from the London Clay Formation (Ypresian, England) in the NHMUK are stored in silicone oil to retard decay processes. X-ray micro-computed tomography (micro-CT) has revealed internal morphology for multiple holotypes (including severely cracked and encrusted specimens) scanned in the protective fluid. Silicone oil alone has a similar X-ray attenuation to parts of the specimens, causing minor uncertainty for digitally rendered surfaces, but key systematic characters are readily visualised. Further work is needed to optimise visualization of fine-scale cellular detail. Labelling and segmentation to visualise important structures is achievable with these micro-CT datasets. However, manual labelling of individual slices is required and defining boundaries between features can be difficult due to differential pyritization and silicone oil permeation. Digital sections through specimens can be made in any orientation and digital locule casts can be produced for studies in virtual taphonomy. These achievements have been accomplished with minimal risk to specimens, which remained in silicone oil and were studied within the museum. The datasets provide a potentially permanent record of at-risk specimens, can be made widely available to researchers unable to visit the collections and to other interested parties, and they enable monitoring for future conservation.
\end{abstract}

Key words: early Eocene; fossil plants; fruits and seeds; London Clay Formation; microCT; Natural History Museum, London (NHMUK). 


\section{Introduction}

The London Clay Formation (Ypresian) exposed in southeast England contains one of the most diverse early Eocene biotas with fossils of marine and terrestrial life. Plants are the most common fossils from the terrestrial realm. There is a large, well-illustrated field guide, covering the common elements of the biota (Rayner et al. 2009). Marine invertebrates (e.g., Tracey et al. 2002) include nautilids (Dzik and Gaździcki 2001) and teredinid bivalves, which bored into wood (Huggett and Gale 1995). Marine vertebrates include sharks (Casier 1966; Hooker et al. 1980), teleost fish (e.g., Beckett and Friedman 2015), and turtles (Hooker et al. 1980). Despite the large number of plant fossils, land mammals are extremely rare: the Isle of Sheppey site has yielded only seven specimens. The mammals include two plesiadapiforms (Toliapina and Platychoerops) and an equoid perissodactyl (Hyracotherium) (Hooker 1994; Hooker et al. 1999; Rayner et al. 1999), as well as the creodont Argillotherium (Davies 1884) and a nyctithere (Leptacodon; fig. 3B in Smith and Smith 2003). Insects are also rare (Jarzembowski 1992; Štys 2010) while birds are slightly more common (e.g., Dyke and Cooper 2000; Walsh and Milner 2011).

J.S. Bowerbank, who collected and purchased fossils from the Isle of Sheppey, gave the public access to his collection and helped found the London Clay Club and subsequently the Palaeontographical Society (Robinson 2003). Bowerbank (1840) first monographed part of the fruit and seed flora and his collection was purchased by what is now known as the Natural History Museum, London (NHMUK) in 1865. Reid and Chandler (1933) and Chandler $(1961,1978)$ completed monographs on the flora using the NHMUK collection and revised Bowerbank's work. Collinson (1983) produced a field guide to the fruits and seeds, also summarizing the stratigraphy of the floras and taxa, 
issues concerning their conservation, the range of collecting sites, types of preservation and paleoenvironmental implications. Earlier literature on fossil plants from the London Clay Formation was outlined by Collinson and Cleal (2001), who reviewed the flora in the context of the designation of several fossil-rich sites as UK Sites of Special Scientific Interest (SSSI).

Based on published data and collections in NHMUK, the fruit and seed flora contains up to at least 500 species of which 350 have been formally named and about 250 of those are of common occurrence (Collinson 1983). Mai (1995) used the flora from the London Clay Formation on the Isle of Sheppey as the basis for the definition of an early Eocene 'Florenkomplex Belleu-Sheppey' in Europe. Records of genera from the London Clay Formation are being used in current research, including for calibration of phylogenies, understanding phytogeography and dispersal patterns, and for comparison with modern plants and other fossil floras (e.g., Chen and Manchester 2007; Jacques et al. 2007; Collinson et al. 2012a; Sarkinen et al. 2013 and in progress; Weeks et al. 2014; Eriksson 2014). There is no other flora with comparable diversity in the Ypresian of Europe and possibly the world. The flora is therefore a global benchmark for the interpretation of plant evolution, biogeography, vegetation and paleoenvironments during the Early Eocene Climatic Optimum (EECO).

There has been no comprehensive revision of the flora since the publication by Chandler (1961). Nevertheless, some elements of the London Clay flora have been subject to recent systematic revision (e.g., Manchester et al. 2007, 2010; Doyle et al. 2008; Manchester 2011. These treatments, like the earlier investigations, relied on physical fracture surfaces and/or sectioning to provide details of internal structure and 
anatomy. Damage from such methods, compounded by natural pyrite decay, threatens the longevity of archived specimens. Given this fact, the importance of the flora, and proof of concept based on study of a single specimen by DeVore et al. (2006), a new project has begun to re-examine the fruits and seeds, especially holotypes, using X-ray microcomputed tomography (micro-CT). The selection of families for study is partly based on existence of ongoing or completed research by others on modern comparative material and/or related fossils from other areas of the world. Based on new observations of six families and 47 species, the suitability of micro-CT for study of structurally preserved fruits and seeds from the London Clay Formation, conserved in silicone oil, is critically evaluated in this paper.

\section{Review of radiographic studies for imaging plant fossils}

Dawson et al. (2014) compared neutron and X-ray imaging for an Eocene araucarian leafy branch enclosed within a carbonate nodule. The neutron imaging produced superior data in that case but facilities for this approach are limited and the method is more appropriate for larger specimens.

By contrast, instruments for micro-CT are more widely available. Although diffuse X-ray methods were applied to fossil fruits in previous decades, e.g., for Spirematospermum (Koch and Friedrich 1972) and Crepetocarpon (fig. 6 in Dilcher and Manchester 1988), to our knowledge, the earliest uses of higher resolution methods employing micro-CT to plant fossils include Pika-Biolzi et al. (2000), Nishida (2001), and Nishida et al. (2001a, 2001b). Nishida spoke in 2001 at various conferences in Japan on the application of CT to permineralized plant fossils but the abstracts are not widely 
available. Nishida (2001, fig. 2) shows images from micro-CT scans. He continued to report his work in short articles on permineralized plants including a few micro-CT images and at conferences in Japan and China (Nishida 2005, 2007a, 2007b; Nishida and Otodani 2007; Nishida et al. 2008) and at the International Organisation of Palaeobotany Conferences (IOP) in Bonn (Nishida 2008) and Tokyo (Nishida and Kotaka 2012).

Micro-CT has now become quite frequently used in the study of plant fossils, including in recent literature on fruits and seed cones (e.g., Collinson et al. 2012b; Feng et al. 2014; Gee et al. 2014; Herrera et al. 2015; Rozefelds et al. 2015; Spencer et al. 2015; Su et al. 2015; Crepet et al. 2016) and was used by DeVore et al. (2006) to study a fruit from the London Clay Formation. Spencer et al. (2013) combined micro-CT imaging with study of subsequently produced wafered sections to obtain requisite cellular detail.

Although with far fewer existing instruments compared to micro-CT, synchrotron radiation X-ray tomographic microscopy (SRXTM) is also becoming more widely used for the study of plant fossils (e.g., Friis et al. 2011, 2014, 2015; Smith et al. 2008, 2009a, 2009b, 2015; Collinson et al. 2012a, 2012b; Steart et al. 2014; Moureau et al. 2016; and references cited in all of these). Collinson et al. (2012b) compared imaging results from micro-CT and SRXTM on an organically preserved fruit from the Eocene of Messel noting that SRXTM provided clearer cellular detail than micro-CT.

\section{Previous applications of $X$-ray imaging to study specimens containing iron pyrite and fossils from the London Clay Formation}

There are several examples of material containing iron pyrite that have been studied by micro-CT. These include: structures interpreted as colonial organisms from the 
Paleoproterozoic (El Albani et al. 2014); a pseudoscorpion encased in amber containing highly X-ray attenuating crystals inferred to be pyrite (Henderickx et al. 2013); and fossils from an exceptionally preserved biota from the Devonian Hunsrück slates in Germany (e.g., Kühl et al. 2012). Most Hunsrück fossils contain iron pyrites and these were some of the first fossils to be studied with X-rays by Stürmer from 1968 onwards (Bartels et al. 1998). The scorpion studied by Kühl et al. (2012, p. 777) is stated to be "completely mineralized with pyrite". In the Hunsrück material the iron pyrites serves to provide contrast, "highlighting" the overall morphology of the fossil and enabling it to be distinguished by X-ray attenuation from the mudstone matrix (Bartels et al. 1998).

In palaeobotany, Strullu-Derrien et al. (2014) studied a small area (a ca. $2 \mathrm{~mm}$ cube) within a $10 \mathrm{~mm} \times 8 \mathrm{~mm} \times 3 \mathrm{~mm}$ piece of iron pyrite permineralized woody axis from an early Devonian plant using propagation phase contrast X-ray synchrotron microtomography (PPC-SR $\mu C T$ ). Strullu-Derrien et al. (2014) succeeded in digitally dissecting out the iron pyrite in some areas to reveal the organic tracheid walls and hence reconstruct the hydraulic properties of the wood. DeVore et al. (2006) studied one iron pyrite permineralized fruit of Palaeorhodomyrtus subangulata (Bowerbank) Reid and Chandler from the London Clay Formation by high resolution X-ray computed tomography (HRXCT). They recovered taxonomically useful information at a resolution of $100 \mu \mathrm{m}$ and concluded that the method would be suitable for application to all London Clay iron pyrite permineralized fossils.

Beckett and Friedman (2015), Friedman et al. (2015), and Johanson et al. (2015) used micro-CT to study the anatomy of fish skulls from the London Clay Formation of the Isle of Sheppey. Walsh and Milner (2011 and references therein) studied bird skulls 
from the London Clay Formation using micro-CT with a focus on obtaining digital endocranial casts. These studies used the same micro-CT instrumentation as in this paper. The fish and bird fossils are preserved in clay-rich calcium carbonate- or phosphatecemented nodules/concretions (Friedman et al. 2015), sometimes with pyritization around the bones, and hence are very different from the iron pyrite permineralized plant fossils studied here. Some fruits, especially of the Nypa palm, do however occur in these types of nodules (Collinson 1983, pers. obs.). Friedman et al. (2015, p. 182) state: "Hard parts in both phosphatic and calcareous concretions tend to be pyritized to some extent... While moderate, uniform pyritization can improve the contrast obtained from CT scans (contrast between fossil and matrix may be low when pyritization has not occurred), excessive pyritization obscures the boundaries between fossil and matrix and can substantially hinder the processing of CT data".

\section{Premise of the research}

Iron pyrite permineralized fossils are subject to decomposition when exposed to oxygen and high humidity (Collinson 1983; Newman 1998). Iron sulfide breaks down into sulfates and subsequently to sulfuric acid. Once begun, this reaction self-catalyses and a specimen can be totally destroyed (along with its paper label and paper container!). Furthermore, if the reaction has begun inside a fruit or seed it may continue invisibly until it reaches the exterior. After treatment with gaseous ammonia, to remove existing decay products, the plant fossils from the London Clay Formation in NHMUK are currently stored in silicone oil to limit or prevent these problems. Temporary removal of silicone oil from the surface of specimens (e.g., for macrophotography or light 
microscopy) requires washing in toluene and places specimens at risk because of the exposure to humid air and the shrinkage of outer layers of organic material when exposed to air. All specimens remain permanently at risk on exposure and should preferably not be removed from the silicone oil. This should be taken into account for all ongoing and future research on the specimens.

To maximise its utility for multiple research themes, information from the global benchmark flora of the London Clay Formation should be as widely available as possible. Specimens stored in silicone oil can be difficult to provide on loan (especially with recent restrictions on fluids in hand luggage for air travel) and the silicone oil storage is inconvenient for light microscope observation and photography. Holotypes are the key specimens for each species and maximum possible information should be extracted from those. However, many curators, and several of the current authors, including the senior author, consider that holotypes and figured specimens should not be destructively analysed - e.g., by physically fracturing or sectioning — regardless of the information that might be gained. Furthermore, NHMUK places appropriate restrictions on the number of type and figured specimens that can be loaned at any one time, thus limiting comparative study unless the collections can be visited.

X-ray micro-computed tomography (micro-CT) of specimens, without removing them from the silicone oil, should provide a method that mitigates these issues and meets the aim to make information widely available.

\section{Material and Methods}


Stratigraphic context of floras-King (1981) divided the Ypresian London Clay

Formation into lettered divisions A-E, oldest to youngest. Collinson (1983, text-fig. 1) inferred the stratigraphic intervals containing the floras, the youngest flora being from the Isle of Sheppey site (divisions D and E) and the oldest from Herne Bay (division A2) and Harwich (division A1). The site of Bognor (divisions B1 and B2) is intermediate in age (Collinson 1983). King (1984) identified the upper part of division $\mathrm{C}$ at the base of the cliffs at Sheppey and King (2016, p. 364 and 367) differentiated a new division F at the top of the cliffs at Sheppey. Division F was formally named as the Hadleigh Member (King 2016, p. 369). Therefore, the possible range of sources for plant fossils, almost all of which have been collected loose on foreshore of the Isle of Sheppey, must now be extended to be from upper division $\mathrm{C}$ to division $\mathrm{F}$.

According to King (2016, p. 366) the dinoflagellate Wetzeliella astra is recorded in the lowest part of division A2 and the First Appearance Datum (FAD) of Wetzeliella meckelfeldensis is just above the last appearance of $W$. astra at Herne Bay. The FAD of W. astra is correlated to the middle of calcareous nannoplankton zone NP 10 at ca. $55 \mathrm{Ma}$ and the FAD of $W$. meckelfeldensis has a slightly younger age of ca. $54.6 \mathrm{Ma}$ (Vandenberghe et al. 2012, fig. 28.9). Therefore, the oldest age for the flora from division A2 at Herne Bay is between 55 and 54.6 Ma.

According to King $(1981 ; 1984 ; 2016$, p. 366) the FAD of the dinoflagellate Dracodinium varielongitudum is in the lower part of division $\mathrm{C}$ in the London area and the FAD of Charlesdownieia coleothrypta occurs in the upper part of division D at Sheppey with that dinoflagellate zone being recorded up to the top of division E. The FAD of C. coleothrypta is correlated to the middle part of calcareous nannoplankton zone 
NP12 and dated to ca. 52.7 Ma by Vandenberghe et al. (2012, fig. 28.9). Chron C24r has been recognised from the base of division A2 to the top of division A3 in boreholes in the Isle of Sheppey, the base of subchron C24n.3n occurs at the base of division B, and the base of Chron C23r is within the upper part of division C (King 2016, p. 367). Chron C23n is documented in divisions E and F at Sheppey (King 2016, p. 367). Therefore, using Vandenberghe et al. (2012, fig. 28.9) the age range for the plant fossils from the Isle of Sheppey is between ca. 53.5 Ma and ca. 51.5 Ma.

The youngest part of the London Clay Formation is considered to be coeval with the oldest part of the Bracklesham Group at Bracklesham Bay. All of the Wittering Formation (Bracklesham Group) is also Ypresian in age but most is slightly younger than the London Clay Formation (correlation by Hooker and Collinson in Collinson 1996). The stratigraphic context of all the Ypresian and Lutetian floras from southern England is summarised by Hooker and Collinson in Collinson (1996) and by Collinson and Cleal (2001). Further discussion of the London Clay Formation geology and stratigraphy can be found in Friedman et al. (2015) and King (2016).

Selection of specimens for study-All fossils studied are in the NHMUK collections. Specimens are selected for study in the following order of priority: (i) holotype; (ii) other types; (iii) other specimens figured at the time the species was described; (iv) other specimens figured by Reid and Chandler (1933) or Chandler (1961); (v) other specimens listed by Reid and Chandler (1933) or Chandler (1961); (vi) other specimens identified by Reid or Chandler based on specimen labels; (vii) other specimens identified by Hazel Wilkinson or Margaret Collinson. In the majority of cases it has been possible to study 
holotypes or other specimens figured at the time of the original description. Forty-seven species have been studied with multiple specimens in a few cases.

Micro-CT methods - The fossils were scanned by micro-CT at the Imaging and Analysis Centre (NHMUK) using a Nikon Metrology HMX ST 225. Ideally, specimens would be scanned in the glass tubes in which they are housed in the collections to avoid any handling. However, glass tends to produce beam hardening and scattering artefacts and also a means would have to be found to stabilise specimens within the tube during the rotation of the scanning. Therefore, specimens were placed in a pool of silicone oil in cavities cut into small blocks of Plastazote ${ }^{\circledR}$ foam with the specimen resting on the foam for stability. Scanning was undertaken using a tungsten reflection target, at an accelerating voltage of $220 \mathrm{kV}$ and current of $200 \mu \mathrm{A}$ with an exposure time of $708 \mathrm{~ms}$ (giving a scan time of 38 minutes). A copper filter $(1.5,2.0$ or $2.5 \mathrm{~mm}$ thickness) was used and 3,142 projections were taken over a $360^{\circ}$ rotation. The voxel sizes of the resulting datasets varied from 6 to $19 \mu \mathrm{m}$ depending on specimen size. Threedimensional volumes were reconstructed using CT Pro (Nikon Metrology, Tring, UK) and TIFF stacks exported using VG Studio Max (Volume Graphics GmbH, Heidelberg, Germany). Datasets were visualized, and images and videos were captured, using Avizo 8.1 (FEI Visualization Science Group, Bordeaux, France). Images were adjusted overall uniformly for contrast and brightness using Adobe ${ }^{\circledR}$ Photoshop ${ }^{\circledR}$ CS2 or CS6. Images have not been adjusted to remove the silicone oil. Micro-CT scan datasets are archived at NHMUK. 


\section{Results}

Enabling systematic revision-The suitability of the micro-CT approach, including its focus on holotypes, for systematic revision leading to reinterpretation of modern genera and extinct taxa in the London Clay flora is demonstrated for Icacinaceae by Stull et al. (this volume). Work including systematic revision is underway for several additional plant families from the London Clay, including Anacardiaceae (Herrera, Manchester, and Collinson in progress), Cyperaceae (Smith, Collinson, and Simpson in progress), Mastixiaceae (Manchester and Collinson in progress), Meliaceae (DeVore and Pigg pers. comm. Kathleen Pigg April 2016) and Symplocaceae plus Styracaceae (Manchester, Fritsch, and Collinson in progress). In addition, a specimen formerly assigned to Anacardiaceae has been identified to Torricelliaceae (Manchester et al. 2015) and comparative work on modern genera is currently in progress.

Visualizing cellular detail-Using the current routine micro-CT methods, with no attempt to maximise ability to visualise cellular detail, the Lagenoidea fruit V68618a (Fig. 1A) does not show any cells in digital transverse section (DTS) of a cut slab (Fig. 1B). Cells are, however, clearly visible by light microscopy (LM) in polished surfaces of both the slab of the specimen used for micro-CT (Collinson pers. obs. March 2016) and in the slab studied previously by LM (Fig. 1C). The latter slab is now severely cracked and pervaded by iron pyrite decay products and is hence no longer suitable for micro-CT. In the Cranmeria fruit V30347b (Figs. 1D, E), the LM images of the polished slab (Fig. 1D) show excellent cellular detail of the seed coat (Fig. 1G), whilst the micro-CT visualizes the larger cells in the outer layer of some seeds but not in others (Fig. 1F, H). DeVore et 
al. (2006), using micro-CT, observed similar large seed coat cells (ca. 300 $\mu \mathrm{m}$ diameter) in some seeds of Palaeorhodomyrtus subangulata (Bowerbank) Reid and Chandler. The internal structure of the holotype of Cornus ettingshausenii (Gardner) Eyde (Cornaceae) (Figs. 2A-C) is seen for the first time here by micro-CT. Cellular detail is not evident (Fig. 2B), though all other features are very clear (resin bodies, planes of weakness of germination valves, locules).

\section{Determining condition of specimens - In Choerospondias sheppeyensis (Reid and} Chandler) Chandler (Anacardiaceae) all specimens are either in pieces or riddled with cracks (Figs. 2D-G). Nevertheless relevant features of fruit organization (locules and iron pyrite-filled lacunae) can be seen in the holotype and in Fig. 2F. The condition of these specimens contrasts strikingly with that of the holotype of another Anacardiaceae fruit, Pseudosclerocarya subalata Reid and Chandler, which shows no cracks, no alterations to the surface and the same relevant features of internal organisation (Fig. 2H-L). In Mastixia parva Reid and Chandler (Mastixiaceae), the appearance of the holotype (Fig. $2 \mathrm{~N}$ ) no longer resembles the original image (Fig. 2M) due to surface modifications. Fortunately, although badly cracked, the inside of the specimen (Fig. 2O) is still adequately preserved to confirm the identification to Mastixia.

A key characteristic of endocarps of the genus Iodes (Icacinaceae) is that the main vascular bundle passes through the endocarp wall from the base to the apex, where it enters the locule (Stull et al. this volume). This is readily visualized for Iodes corniculata Reid and Chandler (fig. 2 in Stull et al. this volume). However, in I. multireticulata the endocarp has been lost entirely from almost all specimens, including those that Reid and 
Chandler (1933) and Chandler (1961) specifically quoted as having the endocarp preserved. Typically, only a remnant remains and is represented by a thin layer of organic material (Figs. 3A, 3D-E) (black colour in light microscopy) attached to an iron pyrite locule cast (Figs. 3A-E). Every specimen of Iodes multireticulata $(>100)$ in the collection was examined visually and the three specimens with the apparent best potential for endocarp preservation were micro-CT scanned. In the holotype V22589 (fig. 4 in Stull et al. this volume) the endocarp is generally well preserved but is incomplete in the critical area of the narrow lateral margin. In another specimen, V22599 (Figs. 3F-J), originally figured by Reid and Chandler (1933), a wide gap is present at the dorsal margin (Fig. 3H) with a narrow gap at the ventral margin and at the apex (Figs. 3F-G) in an otherwise thick, partially pyritized endocarp. Therefore, in contrast to I. corniculata (Figs. 3M-N) it has not been possible to confirm the statement by Reid and Chandler (1933) that in $I$. multireticulata the main vascular bundle passes through the endocarp wall from the base to the apex where it enters the locule.

Some holotypes are in multiple pieces (e.g., four for Xylocarya Reid and Chandler and three for Spondicarya Reid and Chandler) as well as being severely cracked. These specimens are unique and were purposely fractured by Reid and Chandler to reveal internal structure, and further breakage apparently occurred subsequently. These have been scanned and future computational work may enable the pieces to be digitally reassembled into complete fruits.

These variations in, and alterations to, specimens are considered to be due to differential iron pyrite decomposition with formation and subsequent solution of decay 
products. For discussion see Consequences of iron pyrite decomposition, drying out, and removal of decay products on transfer to silicone oil.

Issues with micro-CT scanning in silicone oil-Silicone oil appears as medium gray in typical images (Figs. 3E-G, 3K, 3P-Q, 3S), having a somewhat similar X-ray attenuation to the organic-rich layers of the specimens. As a consequence, it is sometimes difficult to determine the precise position of the edges of the organic layers in the images of the specimens (e.g., Fig. 3K). There can also be problems for automatic thresholding to extract 3D images of specimens (Fig. 3L) and for labelling and segmenting purposes.

Uninformative specimens-Most specimens scanned yielded valuable new information. Only two specimens did not. V22595 (Figs. 3Q-S), described by Reid and Chandler (1933, p. 327) as an internal cast of a seed of Iodes multireticulata "with adherent remains of the endocarp-cast," shows some suggestion of a thick outer layer of iron pyrite (possibly an endocarp cast) in the digital longitudinal section (DLS; Fig. 3S) but this is not evident in the DTS (Fig. 3Q). Small areas of external organic material are tentatively distinguishable from silicone oil in both planes of section (Figs. 3Q, 3S). Although the micro-CT imaging has yielded new information it is difficult to interpret this botanically. Specimen V22726, Icacinicarya sp. 12 of Reid and Chandler (1933), was chosen for scanning because it was well preserved in 3D and because it was an example of an unnamed Icacinicarya species. The apical view in the isosurface (Fig. 3O) provides a clearer image of the specimen than the original images of lateral views (pl. 16, figs. 40 
and 41 in Reid and Chandler 1933), but the DTS shows only uniform iron pyrite surrounded by silicone oil (Fig. 3P).

Labelling, segmentation and thresholding-The internally complex, capitulum-like infructescence of Polycarpella caespitosa (Reid and Chandler 1933) emend. Chandler 1978 (Figs. 4A-C) was used to determine if discrete structures visible in digital longitudinal sections of a London Clay specimen scanned in silicone oil could be labelled and visualised. Labelling of an individual fruit, the seed within it and the six "bristles" surrounding it was successfully accomplished (by S.Y. Smith). Digital removal of the fruit wall layers revealed the seed within and the organisation of the surrounding "bristles" (Fig. 4D). The implications of these results are discussed below (see Significance of labelling and digital dissection in Polycarpella).

By contrast to the internal complexity of Polycarpella (Fig. 4), Cranmeria (Figs. 1D-H), Anacardiaceae (Figs. 1D-L) and Cornaceae (Figs. 1A-C), the endocarps of Icacinaceae (Fig. 3) and Mastixiaceae (Figs. 2M-O) typically contain a pyrite infill. In many Icacinaceae this infill could be digitally extracted through thresholding (Figs. 3B-C, $3 \mathrm{M})$ thus revealing the morphology of the locule cast. This is an example of virtual taphonomy (see Virtual taphonomy - visualising locule casts for comparison with other floras and preservation states below). In the Mastixiaceae (Figs. 2N-O) and in some Icacinaceae (e.g., Figs. 3F-J) this was not possible due to the extent to which iron pyrite permineralization had occurred within the organic outer endocarp wall.

\section{Discussion}


Missing cellular detail-It is known that cellular detail is well preserved in a range of plant fossils from the London Clay Formation. These include the components of the “twig-flora", such as fern rachides (Collinson and Ribbins 1977; Ribbins and Collinson 1978; Poole and Page 2000; Collinson 2001), twig woods (e.g., Poole and Wilkinson 2000; Poole et al. 2002 and references therein), and hypocotyls of the mangrove plant, Ceriops (Wilkinson 1981, 1983).

Some polished thick slabs of London Clay fruits studied by high-magnification LM do not show cellular detail-e.g., Curtisia (Manchester et al. 2007, fig. 2) and Ferrignocarpus (Manchester 2011, fig 2). Others do show cellular detail by LM (e.g., Figs. 1C, 1G herein) but only the larger cells are evident in the micro-CT images (Fig. $1 \mathrm{H})$.

Elongate sclereids were documented in LM in one polished slab of Cornus ettingshausenii (Gardner) Eyde by Manchester et al. (2010, fig. 5T), however, they were not evident in the same specimen at lower magnification (Manchester et al. 2010, fig 5F) or in the specimen studied by micro-CT (Fig. 2C herein).

Cellular detail in iron pyrite-permineralized fossils can be revealed or enhanced by the nitric acid etching technique that was applied to fern rachides from the London Clay Formation by Collinson and Ribbins (1977) and described in more detail by Kenrick (1999). The use of this method is not considered appropriate for holotypes and figured specimens, even if they are already cut, because fern material studied by Collinson and Ribbins (1977) disintegrated after nitric acid etching. It is possible that an acid neutralising treatment, such as gaseous ammonia, could prevent further reactions leading 
to damage to specimens but this would need long-term testing to determine survival of fossils.

One possible explanation for the poor visualization of cellular detail by the routine micro-CT methods used here is that the high energy required to penetrate the iron pyrite is reducing detail in the organic material. Collinson et al. (2012b) compared SRXTM (at the TOMCAT beamline, Swiss Light Source, Paul Scherrer Institute, Switzerland) and micro-CT (at NHMUK, as used here for London Clay material) images of an organically preserved, single-seeded Vitaceae fruit from the Eocene of Messel, Germany. Cellular detail was very clear with SRXTM but only tissue level differences were seen by micro-CT (Collinson et al. 2012b). This suggests that the lack of visible cellular detail in many of the fossils from the London Clay Formation is not entirely due to the type of preservation (pyrite permineralization). For most families studied to date, visualizing cellular detail has not been crucial for interpreting their systematic affinities (e.g., Icacinaceae, Stull et al. this volume). However, it clearly would be preferable to obtain this information wherever it is preserved (see Future options for enhancing micro-CT work below).

\section{Consequences of iron pyrite decomposition, removal of decay products on transfer to} silicone oil and surface drying-In some specimens the effects of iron pyrite decomposition are extensive. Figs. 2D-G are representative for specimens of Choerospondias sheppeyensis (Reid and Chandler) Chandler (Anacardiaceae) and it is remarkable, given the extensive cracking, that the specimen is still intact (though with one locule missing). The holotype (Bowerbank collection) is in four pieces, having 
originally been fractured transversely and longitudinally by Reid and Chandler (1933). The most likely explanation for the extensive cracking is the formation of iron pyrite decay products within original minor cracks in the specimen. The crystallization of the decay products widened the cracks and the removal of those decay products (originally achieved using ethanolamine thioglycolate, more recently with gaseous ammonia) prior to transfer to silicone oil then left wide unfilled cracks. There is no obvious reason for the striking contrast in condition between Choerospondias and the essentially unaltered Pseudosclerocarya subalata Reid and Chandler (Figs. 2H-L), another Anacardiaceae also from the Bowerbank collection.

The surface alteration in Mastixia parva Reid and Chandler (Mastixiaceae) (Fig. $2 \mathrm{~N}$ ) is attributed to encrustation of iron pyrite decay products. These products form on, as well as in, specimens as they interact with humid air.

The implications of the problematic case of Iodes multireticulata Reid and Chandler (Icacinaceae) are considered in Stull et al. (this volume). Although the detailed history of individual specimens is not known, many specimens were stored dry originally and were transferred through various fluids and dried again during the transfer to silicone oil. The loss of endocarp is likely to be a consequence of the differential drying, shrinkage and cracking of the external organic endocarp versus the rigid internal iron pyrite locule cast.

In the cases where a thickness of endocarp had survived in Iodes multireticulata, the crucial marginal area in which the vascular bundle should be found was missing. This is clear in the holotype V22589 (fig. 4 in Stull et al. this volume) and in V22599 (Figs. 3F-J). This loss of endocarp may be a consequence of the bundle conduit having been 
infilled with iron pyrite (as is seen in I. corniculata in Figs. 3K, 3M-N), the iron pyrite then suffering decomposition, the acidic decay products reacting with the local organic material and causing it to fall away from the endocarp. Possibly the larger size of $I$. multireticulata made it more vulnerable to this process than I. corniculata.

Should specimens be scanned in silicone oil?-The similarity in X-ray attenuation between silicone oil and organic-rich layers of the specimens (Figs. 3E-G, 3K, 3P-Q, 3S) is presumably due to the infiltration of the oil throughout the organic material. This is a positive point for use of the oil in conservation, but can make it difficult to distinguish the extent of the organic layers in the specimens (Figs. 3K-L, 3N). This causes problems for digital manipulation, such as 3D rendering of true outer surfaces and labelling of organic structures. Silicone oil can be removed from the outside of the specimen by washing in toluene but subsequent study exposes external surfaces of specimens to humid air. An additional risk is damage to, or loss of, outer layers during washing and subsequent drying. Many specimens date from Bowerbank's collection and hence were collected at least 180 years ago (Bowerbank 1840, Robinson 2003). In our opinion, the safety of the specimens, maximizing their potential availability for future generations, is paramount and hence the specimens must be scanned in the silicone oil. Therefore, the issues cannot be avoided at present (but see Future options for enhancing micro-CT work below).

Collections enhancement, conservation and monitoring-The damaged condition of some specimens, contrasting with the excellent condition of others (see Determining condition of specimens above), highlights the need to monitor specimens to determine if 
further deterioration is taking place during long-term storage in silicone oil. The microCT datasets will be valuable for this purpose as they record the condition of the specimens at the time of scanning and are held in a permanent archive at NHMUK. The micro-CT datasets therefore provide a permanent digital record that can be shared with a range of end users. The micro-CT datasets will also reduce future risk to the specimens, because they will need to be removed from the silicone oil for microscope study much less frequently.

Significance of labelling and digital dissection in Polycarpella-The London Clay fruit of Polycarpella caespitosa (Reid and Chandler 1933) emend. Chandler 1978 is of interest for two reasons. Firstly, it was attributed to Cyperaceae by Chandler (1978) and was therefore important for studies of this family in the UK Paleogene (Smith et al. 2008, 2009b). Secondly, it is the only capitulum-like fruit (Figs. 4A-C) in the flora from the London Clay Formation and therefore the only possible candidate that might represent Platanaceae in the flora. The absence of Platanaceae fruits is unexpected based on the twig and wood fossils from the London Clay Formation assigned to Platanaceae (Poole et al. 2002) and the prevalence of the family in the Paleogene (e.g., Manchester 1994).

Digital longitudinal sections of Polycarpella show that the fruits are not grouped into florets (Fig. 4C). There are six 'bristles' surrounding each fruit (Fig. 4D), which are attached to one another beneath the fruit. None of these features are consistent with Platanaceae fossils (e.g., Manchester 1994), but are typical of Cyperaceae. Limited available characters (by contrast to Volkeria, Smith et al. 2009b) have so far prevented 
recognition of a close living relative to Polycarpella but placement in Cyperaceae is considered most likely.

It was necessary to do all the labelling work manually on the digital slices and this was very time consuming. However, the partial pyrite permineralization of organic structures, the artificial 'fusion' of structures due to mineralization, and the presence of silicone oil throughout the specimen meant that automated thresholding could not be used. Automated dissection might be possible in future (see Future options for enhancing micro-CT work below). Although time consuming, the labelling has successfully revealed key characteristics of Polycarpella (Fig. 4D) that were not readily evident from the external surface (Figs. 4A-B) or the digital longitudinal section (Fig. 4C).

\section{Virtual taphonomy - visualising locule casts for comparison with other floras and} preservation states - Virtual taphonomy (Smith et al. 2009a) produces digital fossils for comparison with real fossils in order to obtain, and explain, the different appearances of the same taxon that may result from variations in fossilization processes. Smith et al. (2009a) gave several examples of potential 'virtual' fossils. These included: (i) digital endocarps and locule casts produced by digitally removing outer fruit wall and digitally infilling the locule of modern Menispermaceae fruits; and (ii) digital seeds with varying seed coat appearances resulting from sequential virtual removal of seed coat layers from modern seeds. For the London Clay Icacinaceae it has proven fairly easy to produce digital locule casts by removing the outer fruit layers (through thresholding). This is a new example of virtual taphonomy, where a digital locule cast has been produced from a pyrite infill of the locule of a fossil endocarp. These locule casts can be used for generic 
and specific identification of real fossil locule casts among the London Clay Formation fossils. In Iodes corniculata, for example, the rarity of blind ending ridges in the endocarp (Fig. 3L) is also evident in the locule cast (Fig. 3M). This is important because the outer organic fruit wall layers of London Clay plant fossils are vulnerable to drying and physical damage and hence may be missing. Furthermore, these digital casts can also be studied alongside real fossil locule casts formed of other minerals (e.g., calcite, silica) thus enabling comparison between fossil floras in different preservations states.

Future options for enhancing micro-CT work-The purchase of a state-of-the-art dual energy CT scanner for the Imaging and Analysis Centre at NHMUK opens up new possibilities. Perhaps the silicone oil will be digitally separable from the specimens, despite its similar X-ray attenuation with that of the organic material. The iron pyrite could perhaps be readily separated from the organic material, in a similar manner to the work by Strullu-Derrien et al. (2014), although in some cases iron pyrite dispersed through the organic material might complicate this approach and it may be more difficult with silicone oil. Smaller voxel size and thus higher resolution scans might reveal the fine cellular detail that is currently lacking in micro-CT images. However, the energy of the beams $(\mathrm{kV})$ that some newer, higher-resolution $\mathrm{CT}$ instruments produce may not be high enough to penetrate the iron pyrite sufficiently to produce a scan without significant artifacts that would probably obscure the detail that the higher resolution would aim to provide.

\section{Acknowledgements}


MEC would like to thank Ashley A. Klymiuk, Selena Y. Smith, and Stefan A. Little for inviting her to speak in the colloquium honoring Ruth A. Stockey (at Botany 2015) and Jerry Hooker for discussion of stratigraphy and advice on mammals from the London Clay Formation. The authors thank Peta Hayes for curatorial assistance at NHMUK and Rebecca Summerfield, Farah Ahmed, and Amin Garbout for help with micro-CT scanning. NFA thanks the Palaeontological Association for the award of an Undergraduate Research Bursary (PA-UB201401). SYS thanks the Royal Society for the award of USA/Canada Fellowship to work at Royal Holloway University of London 2007-2009. SRM's participation was supported in part by National Science Foundation grant EAR 1338285. MJA thanks the Department of Earth Sciences, Royal Holloway University of London for a Lyell Bursary. 


\section{References}

Bartels, C., Briggs, D.E.G., and Brassel, G. 1998. The fossils of the Hunsrück Slate: marine life in the Devonian. Cambridge University Press, Cambridge.

Beckett, H.T., and Friedman, M. 2015. The one that got away from Smith Woodward: cranial anatomy of Micrornatus (Acanthomorpha: Scombridae) revealed using computed microtomography. Geol. Soc., Lond., Spec. Publ. 430: 337-353. doi:10.1144/SP430.16.

Bowerbank, J.S. 1840. A history of the fossil fruits and seeds of the London Clay. John Van Voorst, London.

Casier, E. 1966. Faune ichthyologique du London Clay. British Museum (Natural History), London.

Chandler, M.E.J. 1961. The Lower Tertiary Floras of Southern England. I. Palaeocene Floras, London Clay Flora (Supplement). British Museum (Natural History), London.

Chandler, M.E.J. 1978. Supplement to the Lower Tertiary floras of southern England, part 5. Tertiary Res. Spec. Pap. 4: 1-47.

Chen, I., and Manchester, S.R. 2007. Seed morphology of modern and fossil Ampelocissus (Vitaceae) and implications for phytogeography. Am. J. Bot. 94(9): 15341553. doi:10.3732/ajb.94.9.1534. 
Collinson, M.E. 1983. Fossil Plants of the London Clay. Palaeontological Association Field Guides to Fossils, No. 1. The Palaeontological Association, London.

Collinson, M.E. 1996. Plant macrofossils from the Bracklesham Group (Ypresian and Lutetian), Bracklesham Bay, West Sussex, England: review and significance in the context of coeval British Tertiary floras. Tertiary Res. 16: 175-202.

Collinson, M.E. 2001. Cainozoic ferns and their distribution. Brittonia, 53(2): 173-235. doi:10.1007/BF02812700.

Collinson, M.E., and Ribbins, M.M. 1977. Pyritised fern rachides in the London Clay. Tertiary Res. 1(4): 109-113.

Collinson, M.E., and Cleal, C.J. 2001. Early and early-middle Eocene (YpresianLutetian) palaeobotany of Great Britain. In Mesozoic and Tertiary Palaeobotany of Great Britain, Geological Conservation Review Series, No. 22. Edited by C.J. Cleal, B.A. Thomas, D.J. Batten, and M.E. Collinson. Joint Nature Conservation Committee, Peterborough. pp. 185-226.

Collinson, M.E., Manchester, S.R., and Wilde, V. 2012a. Fossil fruits and seeds of the Middle Eocene Messel biota, Germany. Abh. Senckenb. Naturforsch. Ges. 570: 1-251. 
Collinson, M.E., Smith, S.Y., Manchester, S.R., Wilde, V., Howard, L.E., Robson, B.E., Ford, D.S.F., Marone, F., Fife, J.L., and Stampononi, M. 2012b. The value of X-ray approaches in the study of the Messel fruit and seed flora. Palaeobiodivers. Palaeoenviron. 92(4): 403-416. doi:10.1007/s12549-012-0091-7.

Crepet, W.L., Nixon, K.C., Grimaldi, D., and Riccio, M. 2016. A mosaic Lauralean flower from the Early Cretaceous of Myanmar. Am. J. Bot. 103(2): 290-297. doi:10.3732/ajb.1500393.

Davies, W. 1884. Notes on some new carnivores from the British Eocene Formations. Geol. Mag. Decade III, 1(10): 433-438. doi:10.1017/S0016756800185802.

Dawson, M., Francis, J., and Carpenter, R. 2014. New views of plant fossils from Antarctica: a comparison of X-ray and neutron imaging techniques. J. Paleo. 88(4): 702707. doi:10.1666/13-124.

DeVore, M.L., Kenrick, P., Pigg, K.B., and Ketcham, R.A. 2006. Utility of high resolution x-ray computed tomography (HRXCT) for paleobotanical studies: an example using London Clay fruits and seeds. Am. J. Bot. 93(12): 1848-1851. doi:10.3732/ajb.93.12.1848. 
Dilcher, D.L., and Manchester, S.R. 1988. Investigations of angiosperms from the Eocene of North America: a fruit belonging to the Euphorbiaceae. Tertiary Res. 9: 45-5

Doyle, J.A., Manchester, S.R., Sauquet, H. 2008. A seed related to Myristicaceae in the Early Eocene of southern England. Syst. Bot. 33(4): 636-646.

doi:10.1600/036364408786500217.

Dyke, G.J., and Cooper, J.H. 2000. A new psittaciform bird from the London Clay (lower Eocene) of England. Palaeontology, 43(2): 271-285. doi:10.1111/1475-4983.00126.

Dzik, J., and Gaździcki, A. 2001. The Eocene expansion of nautilids to high latitudes. Palaeogeogr. Palaeoclimatol. Palaeoecol. 172(3-4): 297-312. doi:10.1016/S00310182(01)00304-2.

El Albani, A., Bengtson, S., Canfield, D.E., Riboulleau, A., Rollion-Bard, C., Macchiarelli, R., Ngombi-Pemba, L., Hammarlund, E., Meunier, A., Moubiya-Mouele, I., Benzerara, K., Bernard, S., Boulvais, P., Chaussidon, M., Cesari, C., Fontaine, C., ChiFru, E., García-Ruiz, J.M., Gauthier-Lafaye, F., Mazurier, A., Pierson-Wickmann, A.C., Rouxel, O., Trentesaux, A., Vecoli, M., Versteegh, G.J.M., White, L., Whitehouse, M., and Bekker, A. 2014. The 2.1 Ga Old Francevillian Biota: Biogenicity, Taphonomy and Biodiversity. PLOS ONE, 9(6): e99438. doi:10.1371/journal.pone.0099438. 
Eriksson, O. 2014. Evolution of angiosperm seed disperser mutualisms: the timing of origins and their consequences for coevolutionary interactions between angiosperms and frugivores. Biol. Rev. 91(1): 168-186. doi:10.1111/brv.12164.

Feng, Z., Rößler, R., Annacker, V., and Yang, J.-Y. 2014. Micro-CT investigation of a seed fern (probable medullosan) fertile pinna from the Early Permian Petrified Forest in Chemnitz, Germany. Gondwana Res. 26(3-4): 1208-1215. doi:10.1016/j.gr.2013.08.005.

Friis, E.M., Crane, P.R., and Pedersen, K.R. 2011. Early flowers and angiosperm origins. Cambridge University Press, Cambridge.

Friis, E.M., Marone, M., Pedersen, K.R., Crane, P.R., and Stampanoni, M. 2014. Threedimensional visualization of fossil flowers, fruits, seeds, and other plant remains using synchrotron radiation X-ray tomographic microscopy (SRXTM): new insights into Cretaceous plant diversity. J. Paleont. 88(4): 684-701. doi:10.1666/13-099.

Friis, E.M., Crane, P.R., Pedersen, K.R., Stampanoni, M., and Marone, F. 2015.

Exceptional preservation of tiny embryos documents seed dormancy in early angiosperms. Nature, 528(7583): 551-554. doi:10.1038/nature16441.

Friedman, M., Beckett, H.T., Close, R.A., and Johanson, Z. 2015. The English Chalk and London Clay: two remarkable bony fish Lagerstätten. Geol. Soc., Lond., Spec. Publ. 430: 165-200. doi:10.1144/SP430.18. 
Gee, C.T., Dayvault, R.D., Stockey, R.A., and Tidwell, W.D. 2014. Greater palaeobiodiversity in conifer seed cones in the Upper Jurassic Morrison Formation of Utah, USA. Palaeobiodivers. Palaeoenviron. 94(2): 363-375. doi:10.1007/s12549-0140160-1.

Henderickx, H., Perkovsky, E.E., Van Hoorebeke, L., and Boone, M. 2013. The first pseudogarypid in Rovno amber (Ukraine) (Pseudoscorpiones: Pseudogarypidae). Phegea, 41(4): 90-92.

Herrera, F., Shi, G., Leslie, A.B., Knopf, P., Ichinnorov, N., Takahashi, M., Crane, P.R., and Herendeen, P.S. 2015. A new voltzian seed cone from the Early Cretaceous of Mongolia and its implications for the evolution of ancient conifers. Int. J. Plant Sci. 176(8): 791-809. doi:10.1086/683060.

Hooker, J.J. 1994. The beginning of the equoid radiation. Zool. J. Linn. Soc. 112(1-2): 29-63. doi:10.1111/j.1096-3642.1994.tb00311.x.

Hooker, J.J., Insole, A.N., Moody, R.T.J., Walker, C.A., and Ward, D.J. 1980. The distribution of cartilaginous fish, turtles, birds and mammals in the British Palaeogene. Tertiary Res. 3(1): 1-2. 
Hooker, J.J., Russell, D.E., and Phélizon, A. 1999. A new family of Plesiadapiformes (Mammalia) from the Old World Lower Paleogene. Palaeontology, 42(3): 377-407. doi:10.1111/1475-4983.00078.

Huggett, J.M., and Gale, A.S. 1995. Palaeoecology and diagenesis of bored wood from the London Clay Formation of Sheppey, Kent. Proc. Geol. Assoc. 106(2): 119-136. doi:10.1016/S0016-7878(08)80144-7.

Jacques, F.M.B., Gallut, C., Vignes-Lebbe, R., Zaragüeta, I., and Bagils, R. 2007. Resolving phylogenetic reconstruction in Menispermaceae (Ranunculales) using fossils and a novel statistical test. Taxon, 56(2): 379-392.

Jarzembowski E.A. 1992. Fossil insects from the London Clay (Early Eocene) of southern England. Tertiary Res. 13: 87-94.

Johanson, Z., Close, R.A., Tyler, J.C. and Friedman, M. 2015. A remarkable new beaked tetraodontiform fish from the early Eocene London Clay Formation, UK. SICB Abstract No. P2-22, Society for Integrative and Comparative Biology Annual Meeting 2015. West Palm Beach, Florida, 3-7 January. Available from http://www.sicb.org/meetings/2015/schedule/abstractdetails.php?id=206 [Accessed 14 March 2016]. 
Kenrick, P. 1999. Opaque petrifaction techniques. In Fossil plants and spores: modern techniques. Edited by T.P. Jones, and N.P. Rowe. Geological Society of London, London. pp. 87-91.

King, C. 1981. The stratigraphy of the London Clay and associated deposits. Tertiary Res. Spec. Pap. 6: 1-158.

King, C. 1984. The stratigraphy of the London Clay Formation and Virginia Water Formation in the coastal sections of the Isle of Sheppey (Kent, England). Tertiary Res. 5(3): 121-160.

King, C. 2016. A revised correlation of Tertiary rocks in the British Isles and adjacent areas of NW Europe. Geol. Soc., Lond., Spec. Rep. 27: 1-719.

Koch, B.E., and Friedrich, W.L. 1972. Stereoskopische Röntgenaufnahmen von fossilen Früchten. Bull. Geol. Soc. Denmark, 21: 358-367.

Kühl, G., Bergmann, A., Dunlop, J., Garwood, R.J., and Rust, J. 2012. Redescription and palaeobiology of Palaeoscorpius devonicus Lehmann, 1944 from the Lower Devonian Hunsrück Slate of Germany. Palaeontology, 55(4): 775-787. doi:10.1111/j.14754983.2012.01152.x.

Mai, D.H. 1995. Tertiäre Vegetationsgeschichte Europas. G. Fischer, Jena. 
Manchester, S. R. 1994. Fruits and seeds of the Middle Eocene Nut Beds Flora, Clarno Formation, Oregon. Palaeontogr. Am. 58: 1-205.

Manchester, S. R. 2011. Fruits of Ticodendraceae (Fagales) from the Eocene of Europe and North America. Int. J. Plant Sci. 172(9): 1179-1187. doi:10.1086/662135.

Manchester, S. R., Xiang, Q.-Y., and Xiang, Q.-P. 2007. Curtisia (Cornales) from the Eocene of Europe and its phytogeographical significance. Bot. J. Linn. Soc. 155(1): 127134. doi:10.1111/j.1095-8339.2007.00680.x.

Manchester, S. R., Xiang, X.-P., and Xiang, Q.-Y. 2010. Fruits of cornelian cherries (Cornaceae: Cornus subg. Cornus) in the Paleocene and Eocene of the Northern Hemisphere. Int. J. Plant Sci. 171(8): 882-891. doi:10.1086/655771.

Manchester, S.R., Collinson, M.E., Herrara, F., Soriano-Hoyuelo, C., and Andrew, M.J. 2015. Fruit morphology and anatomy of modern and fossil Torricelliaceae (Apialies). Botanical Society of America Abstract No. 1277, Botany 2015. Edmonton, Alberta, Canada, 25-29 July. Available from http://2015.botanyconference.org/engine/search/1277.html [accessed 14 March 2016].

Moreau, J-D., Gomez, B., Daviero-Gomez, V., Néraudeau, D., and Tafforeau, P. 2016. Inflorescences of Mauldinia sp. (Lauraceae) and associated fruits from the Cenomanian 
of Languedoc Roussillon, France. Cretaceous Res. 59: 18-29.

doi:10.1016/j.cretres.2015.10.018.

Newman, A. 1998. Pyrite oxidation and museum collections: a review of theory and conservation treatments. Geol. Curator, 6(10): 363-371.

Nishida, H. 2001. The frontier of fossil plant studies. Gakujutu Geppou, 54(12): 11421144 (in Japanese).

Nishida, H. 2005. Cretaceous plants of Japan based on permineralized fossils. Kaseki, 78: 5-20 (in Japanese with English abstract). Available from http://www.palaeo-socjapan.jp/download/Kaseki/Kaseki_online/No78.htm [Accessed 14 March 2016].

Nishida, H. 2007a. Microscopic X-ray CT for the study of permineralized plant fossils. In Proceedings of the International Symposium on Sino-German Cooperation of Geology and Environmental Changes in northern China. Edited by G. Sun, V. Mosbrugger, Y.-W. Sun, and A. Bruch. Ürümqi, China. pp. 28-30.

Nishida, H. 2007b. Investigation of plant evolution using permineralized fossils. Kenbikyou, 42(2): 118-121(in Japanese). doi:10.11410/kenbikyo2004.42.118.

Nishida, H. 2008. Benefits of high resolution X-ray CT for the study of permineralized plants. Abstract volume of the $12^{\text {th }}$ International Palynological Congress (XII IPC) and 
$8^{\text {th }}$ International Organisation of Palaeobotany Conference (VIII IOPC), Joint Congress. Bonn, Germany, 30 August-6 September. pp. 206.

Nishida, H., and Otodani, S. 2007. Use of high resolution X-ray CT for the observation of permineralized plant fossils and its future perspective. $22^{\text {nd }}$ Annual Meeting of Japanese Association of Historical Botany. Osaka Museum of Natural History, Osaka, Japan, 1718 November.

Nishida, H., and Kotake, Y. 2012. 3D observation of fruit-like organs of two extinct gymnosperm groups from the Late Cretaceous of Hokkaido using MXCT. Jpn. J. Palynol. 58: 169. Available from http://ci.nii.ac.jp/naid/110009572534 [Accessed 14 March 2016].

Nishida, H., Usuda, M., and Hirai, H. 2001a. Use of high resolution X-ray CT scanner for plant study and its future perspectives: examples of fossil study. Abstract volume of the $65^{\text {th }}$ Annual Meeting of Botanical Society of Japan, University of Tokyo, Tokyo, Japan. pp. 212 (in Japanese).

Nishida, H., Usuda, M., and Hirai, H. 2001b. Use of microscopic X-ray CT scanner for plant fossil study. Abstract volume of the $16^{\text {th }}$ Annual Meeting of Japanese Association of Historical Botany. pp. 35-36 (in Japanese).

Nishida, H., Sasaki, K., and Uemura, K. 2008. Identification of permineralized fossil based on high resolution X-ray CT images: a gnetalean seed from the Late Cretaceous of 
Iwate, Japan. Abstract volume of the $72^{\text {nd }}$ Annual Meeting of Botanical Society of Japan, Kōchi University, Kōchi, Japan. pp. 179 (in Japanese).

Pika-Biolzi, M., Hochuli, P.A., and Flisch, A. 2000. Industrial X-ray computed tomography applied to paleobotanical research. Riv. Ital. Paleontol. S. 106(3): 369-377.

Poole. I., and Page, C.N. 2000. A fossil fern indicator of epiphytism in a Tertiary flora. New Phytol. 148(1): 117-125. doi:10.1046/j.1469-8137.2000.00739.x.

Poole, I., and Wilkinson, H.P. 2000. Two early Eocene vines from south-east England. Bot. J. Linn. Soc. 133(1): 1-26. doi:10.1006/boj1.1999.0316.

Poole, I., Davies, K.L., and Wilkinson, H.P. 2002. A review of the platanaceous woods from the Eocene paratropical rainforest of south-east England. Bot. J. Linn. Soc. 139(2): 181-191. doi:10.1046/j.1095-8339.2002.00057.x.

Rayner, D., Mitchell, T., Rayner, M., and Clouter, F. 2009. London Clay fossils of Kent and Essex. Medway Fossil and Mineral Society, Rochester.

Reid, E.M., and Chandler, M.E.J. 1933. The London Clay flora. British Museum (Natural History), London. 
Ribbins, M.M., and Collinson, M.E. 1978. Further notes on pyritised fern rachides from the London Clay. Tertiary Res. 2(1): 47-50.

Robinson, E. 2003. Historical Notes: Bowerbank: a forgotten geologist. Geol. Today, 19(6): 219-222. doi:10.1111/j.1365-2451.2004.00436.x.

Rozefelds, A., Dettmann, M., Clifford, T., Hocknull, S., Newman, N., Godthelp, H., Hand, S., and Archer, M. 2015. Traditional and computed tomographic (CT) techniques link modern and Cenozoic fruits of Pleiogynium (Anacardiaceae) from Australia. Alcheringa, 39(1): 24-39. doi:10.1080/03115518.2014.951916.

Sarkinen, T., Bohs, L., Olmstead, R.G., and Knapp, S. 2013. A phylogenetic framework for evolutionary study of the nightshades (Solanaceae): a dated 1000-tip tree. BMC Evol. Biol. 13: 214. doi:10.1186/1471-2148-13-214.

Smith, S.Y., Collinson, M.E., and Rudall, P.J. 2008. Fossil Cyclanthus (Cyclanthaceae, Pandanales) from the Eocene of Germany. Am. J. Bot. 95(6): 688-699. doi:10.3732/ajb.2007390.

Smith, S.Y., Collinson, M.E., Rudall, P.J., Simpson, D.A., Marone, F., and Stampanoni, M. 2009a. Virtual taphonomy using synchrotron tomographic microscopy reveals cryptic features and internal structure of modern and fossil plants. Proc. Natl. Acad. Sci. USA. 106(29): 12013-12018. doi:10.1073/pnas.0901468106. 
Smith, S.Y., Collinson, M.E., Simpson, D.A., Rudall, P.J., Marone, F., and Stampanoni, M. 2009b. Elucidating the affinities and habitat of ancient, widespread Cyperaceae: Volkeria messelensis gen. et sp. nov., a fossil mapanioid sedge from the Eocene of Europe. Am. J. Bot. 96(8): 1506-1518. doi:10.3732/ajb.0800427.

Smith, S.Y., Collinson, M.E., Benedict, J.C., Leong-Škorničková, J., Marone, F., and Parkinson, D. 2015. Revision of putative Alpinia (Zingiberaceae) fossils from the Paleogene and Neogene of western Europe. Palaeontogr. Abt. B. 293(1-6): 101-123. doi:10.1127/palb/293/2015/101.

Smith, T., and Smith, R. 2003. Terrestrial mammals as biostratigraphic indicators in upper Paleocene-lower Eocene marine deposits of the southern North Sea Basin. Geol. Soc. Am., Spec. Pap. 369: 513-520. doi:10.1130/0-8137-2369-8.513.

Spencer, A.R.T., Hilton, J., and Sutton, M.D. 2013. Combined methodologies for threedimensional reconstruction of fossil plants preserved in siderite nodules: Stephanospermum braidwoodensis nov. sp. (Medullosales) from the Mazon Creek lagerstätte. Rev. Palaeobot. Palynol. 188: 1-17. doi:10.1016/j.revpalbo.2012.09.001.

Spencer, A.R.T., Mapes, G., Bateman, R.M., Hilton, J., and Rothwell, G.W. 2015. Middle Jurassic evidence for the origin of Cupressaceae: A paleobotanical context for the 
roles of regulatory genetics and development in the evolution of conifer seed cones. Am. J. Bot. 102(6): 1-20. doi:10.3732/ajb.1500121.

Steart, D.C., Spencer, A.R.T., Garwood, R.J., Hilton, J., Munt, M.C., Needham, J., and Kenrick, P. 2014. X-ray synchrotron microtomography of a silicified Jurassic Cheirolepidiaceae (conifer) cone: histology and morphology of Pararaucaria collinsonae sp. nov. PeerJ, 2: e624. doi:10.7717/peerj.624.

Strullu-Derrien, C., Kenrick, P., Tafforeau, P., Cochard, H., Bonnemain, J.-L., Le Hérissé, A., Lardeux, H., and Badel, E. 2014. The earliest wood and its hydraulic properties documented in c. 407-million-year-old fossils using synchrotron microtomography. Bot. J. Linn. Soc. 175(3): 423-437. doi:10.1111/boj.12175.

Stull, G.W., Adams, N.F., Manchester, S.R., Sykes, D., and Collinson, M.E. this volume. Revision of Icacinaceae from the Early Eocene London Clay flora based on X-ray microCT. Botany, this volume.

Štys, P., 2010. A fossil head of an enicocephalomorphan (Hemiptera: Heteroptera) from England revisited: Identity of the first fossil species of Enicocephalidae from Europe. Eur. J. Entomol. 107(3): 455-460. doi:10.14411/eje.2010.052.

Su, T., Wilf, P., Huang, Y., Zhang, S., and Zhou, Z. 2015. Peaches Preceded Humans: Fossil Evidence from SW China. Sci. Rep. 5: 16794. doi:10.1038/srep16794. 
Tracey, S., Donovan, S.K., Clements, D., Jeffery, P., Cooper, J., Rye, P., and Hensley, C. 2002. Temporary exposures of the Eocene London Clay Formation at Highgate, north London: rediscovery of a fossiliferous horizon 'lost' since the nineteenth century. Proc. Geol. Assoc. 113(4): 319-331. doi:10.1016/S0016-7878(02)80037-2.

Vandenberghe, N., Hilgen, F.J., Speijer, R.P. 2012. The Paleogene Period. In The Geologic Time Scale 2012. Edited by F.M. Gradstein, J.G. Ogg, M.D. Schmitz, and G.M. Ogg. Elsevier B.V., Amsterdam. pp. 855-921. doi:10.1016/B978-0-444-59425-9.00028-7.

Walsh, S., and Milner, A. 2011. Halcyornis toliapicus (Aves: Lower Eocene, England) indicates advanced neuromorphology in Mesozoic Neornithes. J. Syst. Palaeontol. 9(1): 173-181. doi:10.1080/14772019.2010.513703.

Weeks, A., Zapata, F., Pell, S.K., Daly, D.C., Mitchell, J.D., and Fine, P.V.A. 2014. To move or to evolve: contrasting patterns of intercontinental connectivity and climatic niche evolution in "Terebinthaceae" (Anacardiaceae and Burseraceae). Front. Genet. 5: 409. doi:10.3389/fgene.2014.00409.

Wilkinson, H.P. 1981. The anatomy of the hypocotyls of Ceriops Arnott (Rhizophoraceae), Recent and fossil. Bot. J. Linn. Soc. 82(2): 139-164. doi:10.1111/j.1095-8339.1981.tb00956.x. 
Wilkinson, H.P. 1983. Starch grain casts and moulds in Eocene (Tertiary) fossil mangrove hypocotyls. Ann. Bot. 51(1): 39-45. 


\section{Figure captions}

Fig. 1. (A-B) Micro-CT images of basal slab V68618a of a Lagenoidea trilocularis Reid and Chandler fruit, which has been cut into three pieces. (A) Volume rendering, showing base of specimen. (B) Central area of digital transverse section (TS), showing that no cells have been resolved (portion of one locule is missing from the fruit). (C) Central slab V68618b of the same Lagenoidea fruit as in A and B, which has been cut into three pieces; light microscope image of a portion of the polished cut transverse surface showing that cellular detail is preserved in the specimen. (D-H) Slab V30347b from fruit of Cranmeria trilocularis Reid and Chandler. (D) Light microscope image of polished cut transverse surface showing multiple seeds and three locules. (E) Digital TS very close to plane of D for comparison. (F) Detail of digital TS from another plane showing seed coats defining seed positions. (G) Detail from just below center left of D (rotated $90^{\circ}$ counter clockwise) showing two-layered seed coats, the outer layer of which is composed of large cells. (H) Detail of digital TS from another plane for comparison with G; indication of inner layer of seed coat in upper part of right hand seed, large-celled outer layer visualized in two seeds. Scale bars $1 \mathrm{~mm}$ in A-B (scale bar in B also applies to C) and $\mathrm{F} ; 2 \mathrm{~mm}$ in D-E; $0.5 \mathrm{~mm}$ in $\mathrm{G}$ (also applies to $\mathrm{H}$ ).

Fig. 2. (A-L, N-O) Micro-CT images of pyritized fruits (Cornaceae, Anacardiaceae, Mastixiaceae) from the London Clay Formation, southeast England. (A-C) V23022, holotype of Cornus ettingshausenii (Gardner) Eyde (Cornaceae) endocarp. (A) Volume rendering showing planes of weakness for germination valves and four locules. (B) Digital transverse section (TS) showing planes of weakness for germination valves, 
originating at margins of four locules, and multiple resin bodies but no elongate sclereids.

(C) Section through a digital isosurface showing four locules and spherical to ovoid resin bodies. (D-G) V30103, figured specimen (Chandler 1961) of Choerospondias sheppeyensis (Reid and Chandler) Chandler (Anacardiaceae) with severe cracking evident externally and internally. (D-E) Digital isosurfaces of the endocarp. (D) Lateral view, showing the full height of the specimen. (E) The broken surface shows locules. (F) Digital TS showing locules with lacunae between. (G) Digital longitudinal section (LS) showing elongate oval locules. (H-L) V22553, holotype of Pseudosclerocarya subalata Reid and Chandler (Anacardiaceae) in pristine condition, (H-J) Digital isosurfaces of the endocarp unaltered from the Reid and Chandler (1933, pl. XIII figs 29-31) images. (H) Apical, (I) lateral, and (J) basal views. (K) Digital TS showing locules and channels. (L) Digital LS showing locules filling the height of the specimen. (M-O) V22970, holotype of Mastixia parva Reid and Chandler (Mastixiaceae). (M) Specimen in its original condition, viewed by reflected light, (Reid and Chandler 1933, pl. XXV, fig. 10, re-used with permission). (N) Digital isosurface of endocarp covered with subsequently formed pyritic encrustation. (O) Digital TS, with severe cracks but U-shaped locule and germination valve infold clearly visualised. Scale bars $5 \mathrm{~mm}$ in $\mathrm{C}$ (also applies to A and B), D-G, and $\mathrm{N}$ (also applies to $\mathrm{M}$ ); $10 \mathrm{~mm}$ in I (also applies to $\mathrm{H}$ and $\mathrm{J}$ ) and $\mathrm{K}$ (also applies to $\mathrm{L}) ; 1 \mathrm{~mm}$ in $\mathrm{O}$.

Fig. 3. Micro-CT images of pyritized fruits (Icacinaceae) from the London Clay Formation, southeast England. (A-E) V22591, specimen of Iodes multireticulata Reid and Chandler. (A) Volume rendering in ventral view. (B-C) Digital isosurfaces of locule 
cast rendered by thresholding the pyrite. (B) Ventral view. (C) Lateral view. (D) Digital LS. (E) Digital TS. Only a remnant of the endocarp survives seen as a thin layer of organic material (pale gray) around the locule cast in A, D, E. (F-J) V22599, additional specimen of I. multireticulata. (F) Digital TS. (G) Digital LS. F and G show partially pyritised endocarp (mixed X-ray attenuation) with gaps at the apex and ventral and dorsal margins. (H-J) Digital isosurfaces of the endocarp. (H) Dorsal view showing clear gap in the endocarp where tissue is missing. (I-J) Opposite lateral views. (K-N) V22579, holotype of Iodes corniculata Reid and Chandler. (K) Digital TS. (L) Digital isosurface of the endocarp superimposed on the volume rendering in $(\mathrm{N}) .(\mathrm{M})$ Digital isosurface of the locule cast. $(\mathrm{N})$ Volume rendering showing the pyritized locule cast within and the main vascular bundle travelling within the endocarp wall. $\mathrm{K}, \mathrm{L}$ and $\mathrm{N}$ show how the silicone oil causes some difficulty in recognizing and rendering the external organic surface of the specimen. (O-P) V22726, specimen assigned to Icacinicarya sp. 12 by Reid and Chandler (1933). (O) Digital isosurface of the specimen in apical view, a view not illustrated by Reid and Chandler. (P) Digital TS showing only a solid pyrite locule cast. (Q-S) V22595, additional specimen of I. multireticulata, interpreted as an internal cast of a seed with some adherent endocarp cast by Reid and Chandler (1933). (Q) Digital TS. (R) Digital isosurface of the external surface of the specimen in lateral view. (S) Digital LS. Hints of organic endocarp within silicone oil are seen in Q and S, and S seems to show a thick outer layer that may be pyritised endocarp cast. Arrows in F, G, and $\mathrm{K}$ highlight areas where silicone oil can be clearly seen within or surrounding the specimen. Scale bars $5 \mathrm{~mm}$ in D (also applies to A-C), G, H (also applies to I-J), and S 
(also applies to R); $1 \mathrm{~mm}$ in E-F, K, M (also applies to L and N), P (also applies to O), and $\mathrm{Q}$.

Fig. 4. Micro-CT images of a broken pyritized capitulum-like infructescence (V51634) of Polycarpella caespitosa Reid and Chandler emend. Chandler 1978 (Cyperaceae) from the London Clay Formation, southeast England. (A-B) Digital isosurface renderings showing individual fruits. (A) Oblique lateral view, with broken edge showing internal radial features and basal stalk. (B) Oblique apical view. (C) Digital longitudinal section (LS), showing individual fruits not arranged in florets but more like spikelets. (D) Image produced by labelling and segmentation of the micro-CT dataset, showing six 'bristles' surrounding each fruit, which attach to one another beneath the fruit. The fruit wall layers have been removed from around the seed so that all the bristles can be seen. The seed remains visible. Scale bars $=5 \mathrm{~mm}$. 


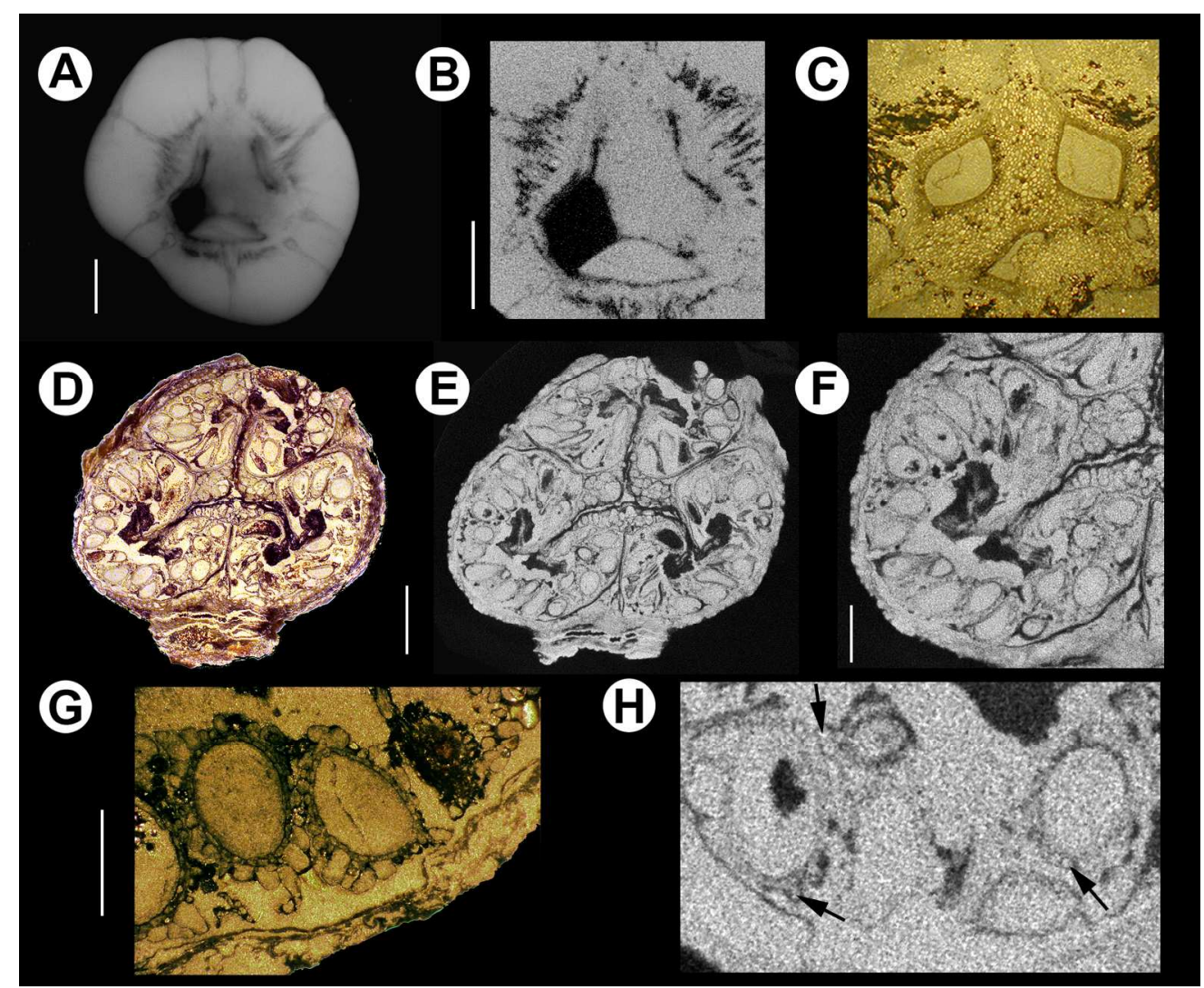

Fig. 1. (A-B) Micro-CT images of basal slab V68618a of a Lagenoidea trilocularis Reid and Chandler fruit, which has been cut into three pieces. (A) Volume rendering, showing base of specimen. (B) Central area of digital transverse section (TS), showing that no cells have been resolved (portion of one locule is missing from the fruit). (C) Central slab V68618b of the same Lagenoidea fruit as in A and B, which has been cut into three pieces; light microscope image of a portion of the polished cut transverse surface showing that cellular detail is preserved in the specimen. (D-H) Slab V30347b from fruit of Cranmeria trilocularis Reid and Chandler. (D) Light microscope image of polished cut transverse surface showing multiple seeds and three locules. (E) Digital TS very close to plane of D for comparison. (F) Detail of digital TS from another plane showing seed coats defining seed positions. (G) Detail from just below center left of D (rotated 90 counter clockwise) showing two-layered seed coats, the outer layer of which is composed of large cells. $(H)$ Detail of digital TS from another plane for comparison with $G$; indication of inner layer of seed coat in upper part of right hand seed, large-celled outer layer visualized in two seeds. Scale bars $1 \mathrm{~mm}$ in A-B (scale bar in B also applies to $C$ ) and $F ; 2 \mathrm{~mm}$ in D-E; $0.5 \mathrm{~mm}$ in $\mathrm{G}$ (also applies to $\mathrm{H}$ ). $182 \times 150 \mathrm{~mm}(300 \times 300 \mathrm{DPI})$ 


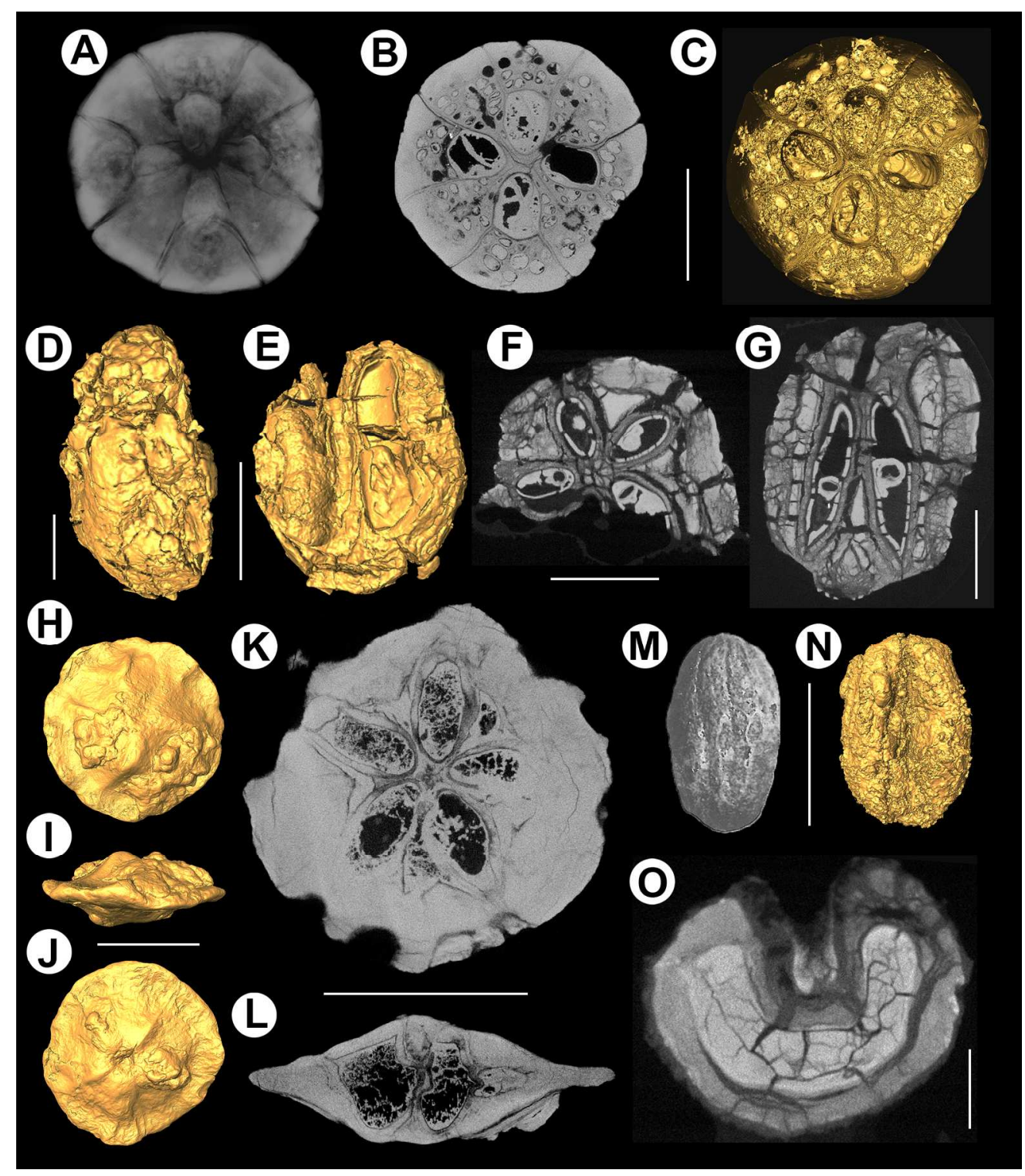

Fig. 2. (A-L, N-O) Micro-CT images of pyritized fruits (Cornaceae, Anacardiaceae, Mastixiaceae) from the London Clay Formation, southeast England. (A-C) V23022, holotype of Cornus ettingshausenii (Gardner) Eyde (Cornaceae) endocarp. (A) Volume rendering showing planes of weakness for germination valves and four locules. (B) Digital transverse section (TS) showing planes of weakness for germination valves, originating at margins of four locules, and multiple resin bodies but no elongate sclereids. (C) Section through a digital isosurface showing four locules and spherical to ovoid resin bodies. (D-G) V30103, figured specimen (Chandler 1961) of Choerospondias sheppeyensis (Reid and Chandler) Chandler (Anacardiaceae) with severe cracking evident externally and internally. (D-E) Digital isosurfaces of the endocarp. (D) Lateral view, showing the full height of the specimen. (E) The broken surface shows locules. (F) Digital TS showing locules with lacunae between. (G) Digital longitudinal section (LS) showing elongate oval locules. (H-L) V22553, holotype of Pseudosclerocarya subalata Reid and Chandler (Anacardiaceae) in pristine condition, $(\mathrm{H}-\mathrm{J})$ Digital isosurfaces of the endocarp unaltered from the Reid and Chandler (1933, pl. XIII figs 29-31) images. (H) Apical, (I) lateral, and (J) basal views. (K) Digital TS showing locules and channels. (L) Digital LS showing locules filling the height of the specimen. (M-O) V22970, holotype of Mastixia parva Reid and Chandler (Mastixiaceae). (M) Specimen in its original condition, viewed by reflected light, (Reid and 
Chandler (1933, pl. XXV, fig. 10). (N) Digital isosurface of endocarp covered with subsequently formed pyritic encrustation. (O) Digital TS, with severe cracks but U-shaped locule and germination valve infold clearly visualised. Scale bars $5 \mathrm{~mm}$ in C (also applies to A and B), D-G, and N (also applies to M); $10 \mathrm{~mm}$ in $\mathrm{I}$ (also applies to $\mathrm{H}$ and $\mathrm{J}$ ) and $\mathrm{K}$ (also applies to $\mathrm{L}$ ); $1 \mathrm{~mm}$ in $\mathrm{O}$. $182 \times 209 \mathrm{~mm}(300 \times 300 \mathrm{DPI})$ 


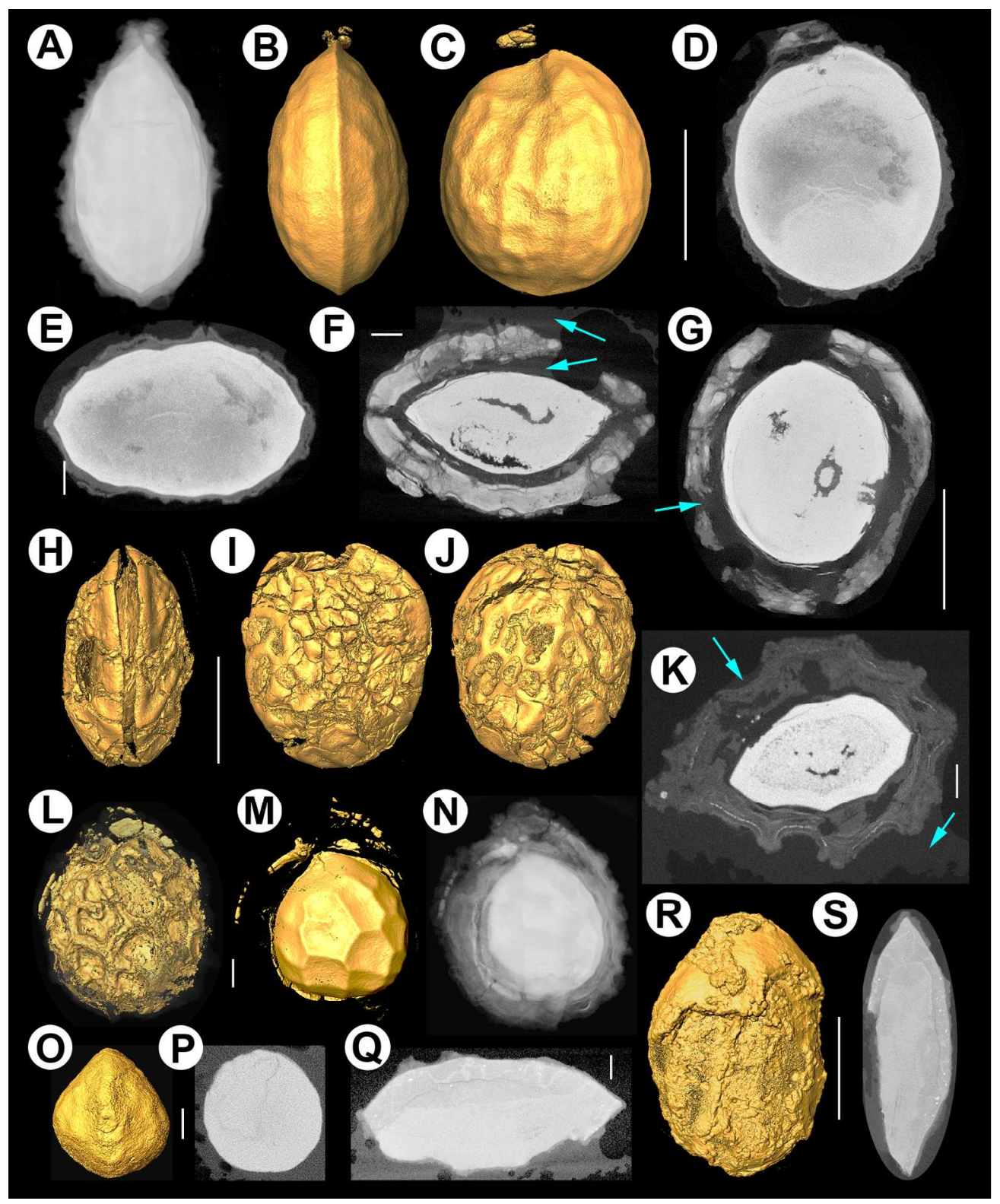

Fig. 3. Micro-CT images of pyritized fruits (Icacinaceae) from the London Clay Formation, southeast England. (A-E) V22591, specimen of Iodes multireticulata Reid and Chandler. (A) Volume rendering in ventral view. (B-C) Digital isosurfaces of locule cast rendered by thresholding the pyrite. (B) Ventral view. (C) Lateral view. (D) Digital LS. (E) Digital TS. Only a remnant of the endocarp survives seen as a thin layer of organic material (pale gray) around the locule cast in A, D, E. (F-J) V22599, additional specimen of I.

multireticulata. (F) Digital TS. (G) Digital LS. F and G show partially pyritised endocarp (mixed X-ray attenuation) with gaps at the apex and ventral and dorsal margins. (H-J) Digital isosurfaces of the endocarp. (H) Dorsal view showing clear gap in the endocarp where tissue is missing. (I-J) Opposite lateral views. (K-

N) V22579, holotype of Iodes corniculata Reid and Chandler. (K) Digital TS. (L) Digital isosurface of the endocarp superimposed on the volume rendering in $(\mathrm{N})$. (M) Digital isosurface of the locule cast. (N) Volume rendering showing the pyritized locule cast within and the main vascular bundle travelling within the endocarp wall. $\mathrm{K}, \mathrm{L}$ and $\mathrm{N}$ show how the silicone oil causes some difficulty in recognizing and rendering the external organic surface of the specimen. (O-P) V22726, specimen assigned to Icacinicarya sp. 12 by Reid 
and Chandler (1933). (O) Digital isosurface of the specimen in apical view, a view not illustrated by Reid and Chandler. (P) Digital TS showing only a solid pyrite locule cast. (Q-S) V22595, additional specimen of I. multireticulata, interpreted as an internal cast of a seed with some adherent endocarp cast by Reid and Chandler (1933). (Q) Digital TS. (R) Digital isosurface of the external surface of the specimen in lateral view. (S) Digital LS. Hints of organic endocarp within silicone oil are seen in $Q$ and $S$, and $\mathrm{S}$ seems to show a thick outer layer that may be pyritised endocarp cast. Arrows in F, G, and $\mathrm{K}$ highlight areas where silicone oil can be clearly seen within or surrounding the specimen. Scale bars $5 \mathrm{~mm}$ in $D$ (also applies to A-C), G, H (also applies to I-J), and S (also applies to R); $1 \mathrm{~mm}$ in E-F, K, M (also applies to L and N), P (also applies to $\mathrm{O})$, and $\mathrm{Q}$.

$182 \times 219 \mathrm{~mm}(300 \times 300 \mathrm{DPI})$ 


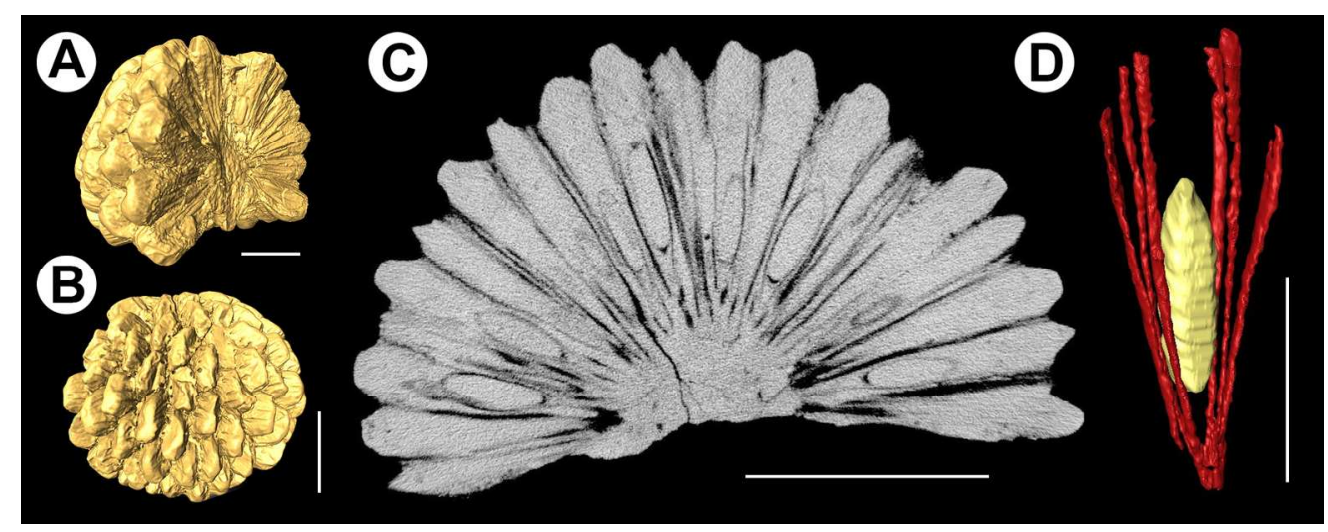

Fig. 4. Micro-CT images of a broken pyritized capitulum-like infructescence (V51634) of Polycarpella caespitosa Reid and Chandler emend. Chandler 1978 (Cyperaceae) from the London Clay Formation, southeast England. (A-B) Digital isosurface renderings showing individual fruits. (A) Oblique lateral view, with broken edge showing internal radial features and basal stalk. (B) Oblique apical view. (C) Digital longitudinal section (LS), showing individual fruits not arranged in florets but more like spikelets. (D) Image produced by labelling and segmentation of the micro-CT dataset, showing six 'bristles' surrounding each fruit, which attach to one another beneath the fruit. The fruit wall layers have been removed from around the seed so that all the bristles can be seen. The seed remains visible. Scale bars $=5 \mathrm{~mm}$. $182 \times 71 \mathrm{~mm}(300 \times 300$ DPI $)$ 